\title{
PEMANFATAN LOKAWISATA BATURRADEN DALAM PENGEMBANGAN PROGRAM PENDDIDIKAN BERBASIS KEUNGGULAN LOKAL (PBKL)
}

\begin{abstract}
Mufida Nofiana
Program Studi Pendidikan Biologi, Universitas Muhammadiyah Purwokerto

E-mail: mu fida.nofiana@yahoo.co.id

Abstract: Baturraden Tourism is a leading tourist attraction located at the foot of Mount Slamet ( $\pm 640 \mathrm{dpl}$ ), about $14 \mathrm{Km}$ north of Purwokerto, Central Java. The location on the slope of the mountain causes the Baturraden area to be found in much mountainous flora and fauna. The utilization of Baturraden Tourism in Education Program Based Local Excellence (PBKL) is integrated with biology subjects because biology based on standard content in the curriculum are included the subject of science with one essence in the form of development skills process. The initial phase of PBKL development is done by analyzing the local potential region and potential schools, developing a subjectspecific pedagogic -based subject program, as well as the integration of the $P B K L$ substance in SK-KD biology subjects as reflected in the developed learning indicators. Analysis of local potential and local potency is done by direct observation and interview. The development of subject-specific pedagogic is done with the development of learning models, learning modules, instructional media, and evaluation instruments based on local excellence. However, the utilization of the Beturraden in the PBKL program is integrated into SK-KD biology so it is expected that students will have excellent competencies such as: being able to utilize local advantage as a source of learning, developing and empowering local excellence as teaching materials and instructional media, applying knowledge in preservation of excellence local, and increase the sense of responsibility in maintaining local excellence
\end{abstract}

Kata kunci: Lokawisata Baturraden, pengembangan, program penddidikan berbasis keunggulan lokal

Lokawisata

Baturraden

merupakan sebuah obyek wisata unggulan yang terletak di kaki Gunung Slamet ( \pm 640 dpl), sekitar $14 \mathrm{Km}$ sebelah utara Purwokerto, Jawa Tengah. Akses jalan yang mudah dan memadai menjadikan lokawisata Baturraden tidak sulit untuk ditempuh dari Purwokerto. Lokawisata Baturraden merupakan kompleks wisata yang sangat luas dimana pengunjung dapat menikmati pemandangan indah lereng Gunung Slamet serta udara pegunungan yang segar dengan suhu $18^{0} \mathrm{C}-25^{\circ} \mathrm{C}$. Lokasi yang berada pada lereng pegunungan menyebabkan daerah Baturraden banyak dijumpai flora dan fauna khas pegunungan. Secara keseluruhan, lokawisata Baturraden sesuai untuk kegiatan rekreasi keluarga maupun perorangan serta menyimpan potensi sebagai sumber belajar khususnya pada mata pelajaran biologi.

Pendidikan

berbasis keunggulan lokal menurut Dwitagama (Asmani, 2012) adalah pendidikan yang memanfaatkan 
keunggulan lokal dalam aspek ekonomi, budaya, bahasa, teknologi informasi, ekologi, dan lain-lain yang semuanya bermanfaat bagi pengembangan kompetensi peserta didik. Salah satu keunggulan lokal yang dapat dijadikan sebagai pendukung pembelajaran berbasis keunggulan lokal antara lain adalah potensi sumber daya alam (SDA) dan potensi geografis. Lokawisata Baturraden dengan segala keunikan yang menjadi ciri khasnya memiliki keunggulan lokal yang dapat dijadikan sebagai pendukung dalam pengembangan pendidikan berbasis keunggulan lokal.

Salah satu implementasi yang dapat dilakukan untuk melaksanakan pembelajaran berbasis keunggulan lokal adalah dengan mengintegrasikannya dalam mata pelajaran tertentu dalam hal ini adalah mata pelajaran biologi. Bahan kajian keunggulan lokal diintegrasikan dengan $\mathrm{SK} / \mathrm{KD}$ mata pelajaran tersebut. Pelaksanaannya dapat dilakukan dengan mengkaji SK/KD mata pelajaran biologi dihubungkan dengan hasil analisis keunggulan lokal. Hasil pengkajian SK/KD tersebut dituangkan pada penyempurnaan silabus dan RPP. Kemudian dibuat bahan ajar cetak berupa modul atau LKS yang mengintegrasikan PBKL pada mata pelajaran biologi. Penilaian pembelajaran berbasis keunggulan lokal yang terintegrasi dalam mata pelajaran biologi menyatu dengan SK dan KD materi yang terkait.

Pemanfaatan

lokawisata Baturraden dalam program pendidikan berbasis keunggulan lokal dilaksanakan secara terintegrasi pada mata pelajaran biologi, sebab mata pelajaran biologi berdasarkan standar isi termasuk dalam rumpun mata pelajaran IPA (sains) dan kelompok mata pelajaran ilmu pengetahuan dan teknologi (IPTEK). Mata pelajaran biologi mempelajari permasalahan yang terkait dengan fenomena alam, baik secara kualitatif maupun kuantitatif, dan berbagai permaslahan yang berkaitan dengan penerapannya untuk membangun teknologi guna mengatasi permasalahan dalam kehidupan masyarakat. Integrasi yang dilakukan merupakan bagian integral dari keseluruhan proses penyelenggaraan pendidikan pada satuan pendidikan.

Pendidikan keunggulan lokal dalam pembelajaran biologi mengarah pada pembelajaran yang bersifat kontekstual. Relevansi pendidikan keunggulan lokal dengan dunia nyata mendorong terbentuknya aplikasi praktis pada pembelajaran kontekstual biologi (Mumpuni, 2011). Objek pembelajaran biologi sanagt mudah ditemukan di lingkungan. Oleh karena itu, guru seharusnya mampu menghadirkan objek tersebut secara nyata baik di dalam kelas mapun tugas terstruktur di luar kelas. Objek yang kontekstual dapat mempermudah 
memahami konsep serta menjadikan pembelajaran lebih bermakna.

Tujuan pelaksanaan program pendidikan berbasis keunggulan lokal dalam pembelajaran bioogi adalah membekali siswa tentang pengetahuan dan sikap menghargai sumberdaya alam beserta potensi yang menjadi keunggulan lokal di daerah setempat. Pemanfaatan lokawisata Baturraden dalam program pendidikan berbasis keunggulan lokal adalah menjadikan lokawisata Baturraden dengan potensi alam yang dimilikinya sebagai sumber belajar dan bahan ajar yang terintegrasi dalam muatan kurikulum biologi kususnya pada materi keanekargaman hayati.

\section{METODE}

Metode yang digunakan pada penelitian ini adalah metode survey dengan teknik yang digunakan adalah observasi dan wawancara. Teknik penelitian yang dilakukan meliputi beberapa tahapan, antara lain: 1) menganalisis potensi lokal daerah yang meliputi sumber daya alam, sumber daya manusia, dan geografis di sekitar wilayah kabupaten Banyumas, Jawa Tengah khususnya daerah di sekitar lokawisata Baturraden untuk mengetahui peluang dan tantangan serta pemanfaatan potensi lokal daerah untuk proses pembelajaran, 2) mengintegrasikan substansi keunggulan lokal dengan SK-KD biologi, 3) mengembangkan indikator pembelajaran. Hasil penelitian yang berupa kajian selanjutnya ditelaah dan dijabarkan dalam bentuk deskriptif untuk mengetahui pemanfaatan lokawisata baturraden dalam pengembangan program pendidikan berbasis keunggulan lokal.

\section{HASIL DAN PEMBAHASAN}

Keunggulan lokal adalah hasil bumi, kreasi seni, tradisi, budaya, pelayanan jasa, sumber daya alam, sumber daya manusia atau lainnya yang menjadi keunggulan suatu daerah (Dwitagama dalam Asmani, 2012). Keunggulan lokal merupakan suatu potensi daerah yang spesifik dimiliki oleh suatu daerah. Keunggulan lokal memanfaatkan potensi daerah menjadi produk atau jasa yang dapat menambah penghasilan daerah serta memiliki keunggulan kompetitif (Ahmadi, dkk., 2012). Pemanfaatan potensi lokal daerah yang khas dalam pengembangan pendidikan sesuai dengan kompetensi, bakat dan minat peserta didik disebut dengan pendidikan berbasis keunggulan lokal. Pendidikan berbasis keunggulan lokal dapat diterapkan pada mata pelajaran biologi. Tahap awal pengembangan pendidikan berbasis keunggulan lokal dilakukan dengan menganalisis potensi daerah.

Pendidikan keunggulan lokal dalam pembelajaran biologi mengarah pada pembelajaran yang bersifat kontekstual. Relevansi pendidikan keunggulan lokal dengan dunia nyata mendorong terbentuknya aplikasi 
praktis pada pembelajaran kontekstual biologi (Mumpuni, 2011). Pembelajaran biologi berperan dalam mengembangkan potensi sumber daya lokal dan membelajarkan tentang bagaimana pemanfaatan dan pelestariannya. Pembelajaran biologi berbasis keunggulan lokal adalah pembelajran biologi yang memanfaatkan potensi lokal setempat untuk meningkatkan pengetahuan dan keterampilan sesuai dengan potensi lokal yang ada.

\section{Analisis potensi daerah}

Sumber belajar melalui potensi lokal merupakan sarana yang membantu siswa mengaitkan materi yang dipelajari dengan keadaan nyata dan mendorong siswa membuat hubungan pengetahuan yang dimiliki dengan penerapan dalam kehidupan (Ahmadi, dkk., 2012). Di kota Purwokerto, lokawisata Baturraden merupakan potensi daerah yang menjadi keunggulan lokal di kota tersebut. Lokawisata Baturraden memiliki sumber daya alam berupa flora maupun fauna khas pegunungan yang dapat dimanfaatkan sebagai sumber belajar. Analisis potensi lokawisata Baturraden sebagai aspek pengembangan pendidikan berbasis keunggulan lokal didasarkan pada tiga komponen, yaitu sumber daya alam, sumber daya manusia, dan potensi geografis.

Tabel 1. Hasil analisis potensi daerah

\begin{tabular}{|c|c|c|c|c|}
\hline No & $\begin{array}{l}\text { Potensi/ } \\
\text { komponen }\end{array}$ & Peluang & Tantangan & Potensi PBKL \\
\hline 1. & $\begin{array}{l}\text { Sumber daya } \\
\text { alam }\end{array}$ & $\begin{array}{l}\text { Lokawisata Baturraden } \\
\text { memiliki obyek wisata alam } \\
\text { yang menarik, antara lain: } \\
\text { - kebun raya Baturraden yang } \\
\text { kekayaan flora dan fauna } \\
\text { khas pegunungan } \\
\text { - pancuran tiga dan pancuran } \\
\text { tujuh yang memiliki sumber } \\
\text { mata air panas belerang } \\
\text { dengan daerah } \\
\text { sekelilingnya banyak } \\
\text { dijumpai lumut dan paku- } \\
\text { pakuan liar banyi banyak } \\
\text { - telaga suna } \\
\text { dijumpai berbagai jenis } \\
\text { tumbuhan baik yang berupa } \\
\text { pohon maupun perdu, lumut, } \\
\text { dan paku-pakuan yang } \\
\text { berada sepanjang perjalanan } \\
\text { dan area sekeliling telaga. }\end{array}$ & $\begin{array}{l}\text { Sumber daya alam } \\
\text { berupa flora dan } \\
\text { fauna belum } \\
\text { banyak } \\
\text { dimanfaatkan } \\
\text { dalam proses } \\
\text { pendidikan }\end{array}$ & $\begin{array}{l}\text { Pemanfaatan } \\
\text { sumber daya alam } \\
\text { sebagai sumber } \\
\text { belajar dan bahan } \\
\text { ajar }\end{array}$ \\
\hline 2. & ber daya manusia & $\begin{array}{l}\text { Di daerah Purwokerto terdapat } \\
\text { banyak sekolah dan } \\
\text { universitas yang memiliki ahli } \\
\text { biologi untuk mengidentifikasi } \\
\text { ragam flora maupun fauna di } \\
\text { lokawisata Baturraden (guru }\end{array}$ & $\begin{array}{l}\text { Tenaga ahli belum } \\
\text { dimanfaatkan untuk } \\
\text { membantu } \\
\text { pelaksanaan } \\
\text { pembelajaran } \\
\text { PBKL. }\end{array}$ & $\begin{array}{l}\text { Pemanfaatan } \\
\text { sumber dari } \\
\text { luar sekolah } \\
\text { untuk } \\
\text { membantu } \\
\text { terlaksananya }\end{array}$ \\
\hline
\end{tabular}




\begin{tabular}{|c|c|c|c|c|}
\hline No & $\begin{array}{l}\text { Potensi/ } \\
\text { komponen }\end{array}$ & Peluang & Tantangan & Potensi PBKL \\
\hline & & $\begin{array}{l}\text { biologi, mahasiswa dan dosen } \\
\text { biologi } \\
\text { Muhammadiyah Purwokerto) }\end{array}$ & & $\begin{array}{l}\text { program } \\
\text { PBKL }\end{array}$ \\
\hline 3. & Geografis & 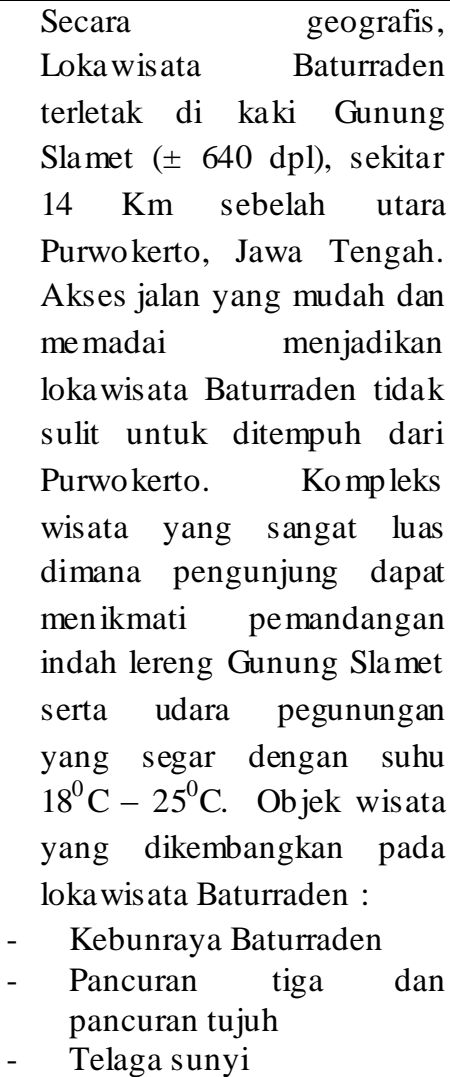 & $\begin{array}{l}\text { Objek wisata belum } \\
\text { banyak } \\
\text { dimanfaatkan } \\
\text { sebagai sumber } \\
\text { belajar }\end{array}$ & $\begin{array}{l}\text { Pemanfaatan } \\
\text { daerah wisata } \\
\text { sebagai sumber } \\
\text { belajar dalam } \\
\text { program } \\
\text { pengembangan } \\
\text { subject spesific } \\
\text { pedagogik } \\
\text { berbasis } \\
\text { keunggulan lokal }\end{array}$ \\
\hline
\end{tabular}

\section{Integrasi substansi PBKL dalam SK-KD dan indikator yang dikembangkan}

Tabe13. Contoh Integrasi substansi PBKL dalam KD mata pelajaran biologi

\begin{tabular}{|c|c|c|c|}
\hline & $\begin{array}{l}\text { Standar } \\
\text { kompetensi }\end{array}$ & Ko mpetensi dasar & Indikator \\
\hline 1. & $\begin{array}{l}\text { Siswa mampu } \\
\text { mengaplikasika } \\
\text { n prinsip-prinsip } \\
\text { pengelompokka } \\
\text { n makhluk } \\
\text { hidup untuk } \\
\text { mempelajrai } \\
\text { keanekaragama } \\
\text { n dan peran } \\
\text { keanekaragama } \\
n \text { hayati bagi } \\
\text { kehidupan }\end{array}$ & $\begin{array}{l}\text { 3.8. Mendeskripsikan dan } \\
\text { mengkomunikasikan ciri-ciri } \\
\text { kingdom plantae dan peranannya } \\
\text { bagi kehidupan }\end{array}$ & 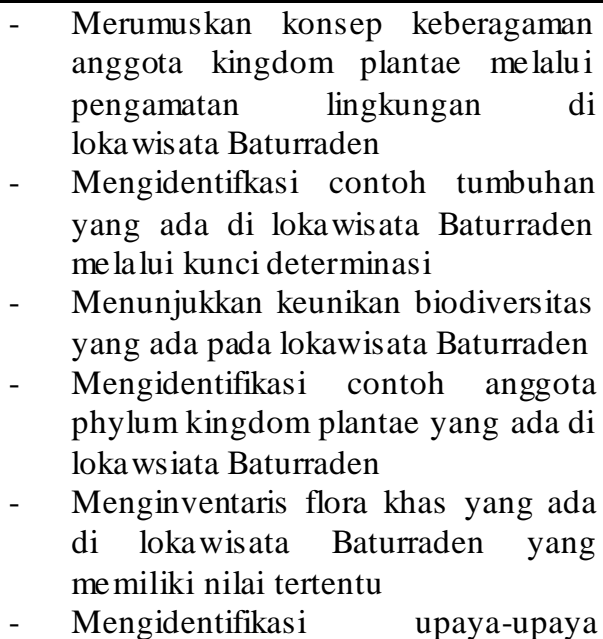 \\
\hline
\end{tabular}




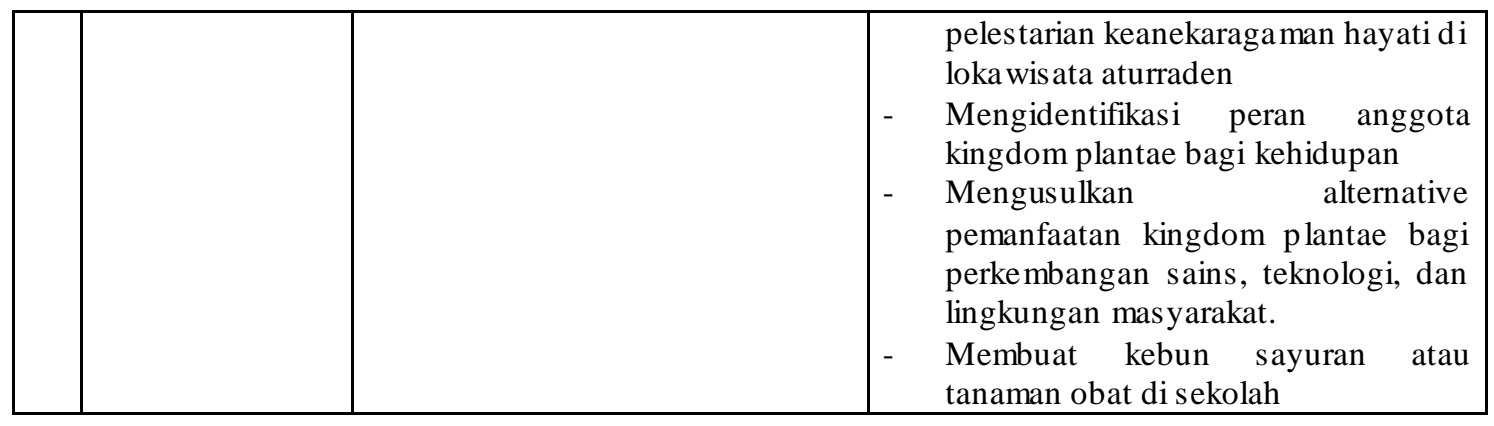

Tabel4. Target kompetensi yang dimiliki oleh peserta didik

\begin{tabular}{|c|c|c|}
\hline No & Program PBKL & Ko mpetensi yang diharapkan \\
\hline 1. & Model pembelajaran berbas is $\mathrm{PBKL}$ & 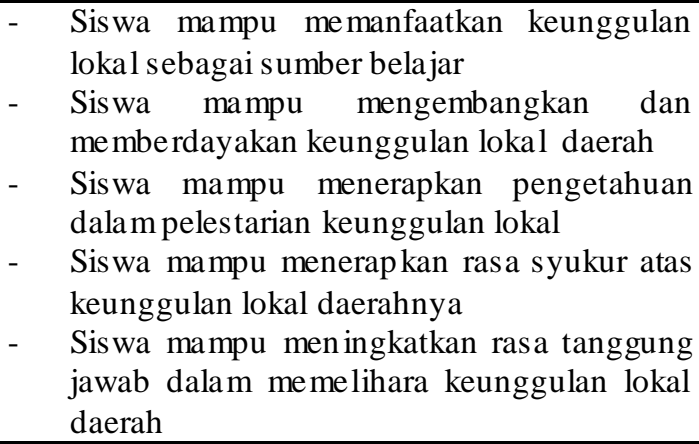 \\
\hline 2. & Modul pembelajaran berbasis $\mathrm{PBKL}$ & 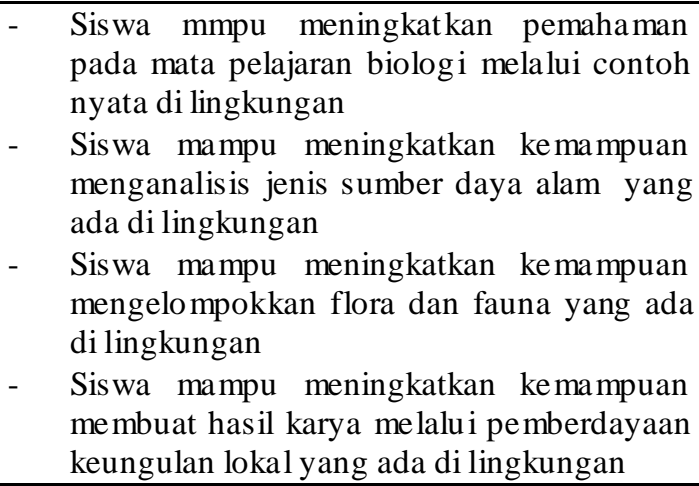 \\
\hline 3. & Media pembelajaran berbas is PBKL & 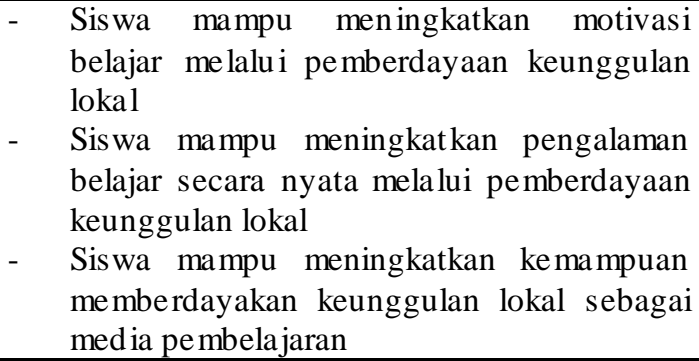 \\
\hline
\end{tabular}

\section{Implementasi pendidikan}

berbas is keunggulan lokal di sekolah diarahkan pada pembelajaran kontekstual biologi sebab objek pembelajaran biologi mudah ditemukan di lingkungan. Oleh karena itu, guru seharusnya mampu menghadirkan objek tersebut secara nyata baik di dalam kelas mapun tugas terstruktur di luar kelas. Objek yang kontekstual dapat mempermudah memahami konsep serta menjadikan pembelajaran lebih bermakna (Mumpuni, 2011). 
Implementasi pendidikan berbasis keunggulan lokal akan melatihkan siswa untuk memiliki kompetensi-kompetensi unggulan antara lain: mampu memanfaatkan keunggulan lokal sebagai sumber belajar, mengembangkan dan memberdayakan keunggulan lokal sebagai bahan ajar maupun media pembelajaran, menerapkan pengetahuan dalam pelestarian keunggulan lokal, serta meningkatkan rasa tanggung jawab dalam memelihara keunggulan lokal.

\section{KESIMPULAN}

Pendidikan berbasis keunggulan lokal adalah usaha untuk mewujudkan pembelajaran yang memanfaatkan keunggulan lokal dalam aspek ekonomi, budaya, teknologi informasi dan komunikasi, bahasa, ekologi, dan lain-lain yang semuanya bermanfaat bagi pengembangan potensi peserta didik. Tujuan pemanfaatan keunggulan lokal dalam penyelenggaraan pendidikan adalah memperkenalkan siswa tentang keunggulan lokal yang ada di daerah masing-masing sehingga dapat dimanfaatkan sebagai sumber belajar dan bahan ajar untuk menunjang pengetahuan, memperkenalkan aspekaspek yang berhubungan dengan keunggulan lokal sehingga nantinya siswa mampu mengolah sumber daya yang ada untuk menunjang kelangsungan kehidupan sekaligus melestarikan sumber daya alam yang menjadi unggulan daerah. Pemanfaatan lokawisata Baturraden dalam program pendidikan berbasis keunggulan lokal adalah menjadikan lokawisata Baturraden dengan potensi alam yang dimilikinya sebagai sumber belajar dan bahan ajar yang terintegrasi dalam muatan kurikulum biologi khususnya pada materi keanekargaman hayati. Implementasi pendidikan berbasis keunggulan lokal dalam pembelajaran biologi akan melatihkan siswa untuk memiliki kompetensi-kompetensi unggulan antara lain: mampu memanfaatkan keunggulan lokal sebagai sumber belajar biologi, mengembangkan dan memberdayakan keunggulan lokal sebagai bahan ajar maupun media pembelajaran yang nyata pada mata pelajaran biologi, menerapkan pengetahuan dalam pelestarian keunggulan lokal, serta meningkatkan rasa tanggung jawab dalam memelihara keunggulan local.

\section{SARAN}

Pendidikan berbasis keunggulan lokal perlu dikembangkan sebagai sarana untuk meningkatkan pemahaman siswa terhadap materi yang didasarkan pada pemanfaatan potensi lokal daerahnya sekaligus menerapkan pengetahuan dalam pelestarian keunggulan lokal, serta meningkatkan rasa tanggung jawab dalam memelihara keunggulan lokal daerah.

\section{DAFTAR RUJUKAN}

Ahmadi, L. K., Amri, S., dan Elisah, T. 2012. Mengembangkan Pendidikan Berbasis Keunggulan Lokal dalam KTSP. Jakarta: Prestasi Pustaka 
Asmani, J. M. 2012. Pendidikan Berbasis Keunggulan Lokal. Yogyakarta: Diva Press

Mumpuni, K. E. 2013. Potensi Pendidikan Keunggulan Lokal Berbasis Karakter dalam Pembelajaran Biologi. Seminar Nasional X Pendidikan Biologi FKIP UNS. 